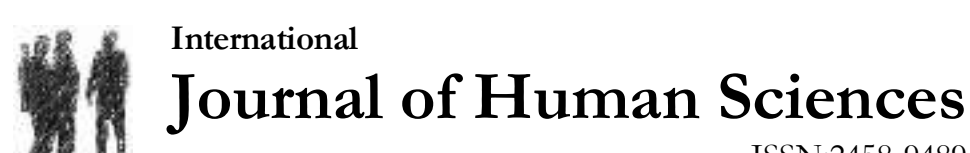 \\ ISSN:2458-9489
}

Volume 14 Issue 3 Year: 2017

\section{Evaluation of the elderly' falls efficacy by their status of having a home accident and daily life activities}

\author{
Hande Şahin ${ }^{1}$ \\ Sibel Erkal ${ }^{2}$
}

\begin{abstract}
A total of 600 older persons from Cebeci district, Ankara province have participated in this study which aimed to evaluate the elderly' falls efficacy by their status of having an accident and daily life activities. Modified Falls Efficacy Scale (MFES), and Katz Daily Activities Scale were used as data gathering tools in this study. The data were analyzed using standard deviation, arithmetic mean, and the student's t-test to compare the two groups, and the analysis of variance in comparison of multiple groups. The results showed that the falls efficacy scores of the older adults who had experienced a home accident within the past year $(\overline{\mathrm{X}}=69,15)$ were lower than those who had not $(\overline{\mathrm{X}}=84,33)$. The falls efficacy scores of the participants decreased with increased dependence in bathing, sitting/standing, toilet, walking, cooking, cleaning and shopping activities. The participants who were older, had lower educational attainment, low monthly income and green cards, and lived with their relatives had lower falls efficacy scores $(\mathrm{p}<0.05)$.
\end{abstract}

Keywords: Elderly; Falls Efficacy; Home Accident; Daily Life Activity.

\section{Introduction}

An increase of the older people is expected in Turkey as in every part of the world. According to the 2013 records of Turkish Statistical Institute; the population of Turkey is 77.696.000; and those who are 65 and above, 6.193.000. Also, it is expected that population above 65 will constitute $10.2 \%, 20.8 \%$ and $27.7 \%$ of the total population in Turkey in 2023, 2050 and 2075 consecutively (TUIK, 2014:7).

With the aging process; biological, psychological and physiological deficiencies occur in older people, they start to face problems related with their daily life activities and visible inabilities appear in their functions. These changes in older people restrict the daily life activities of individuals and negatively affect their life quality (Cinarli \& Koc, 2015: 660). Falling and injuries related with falling are considered as important health problems among the older people. Worldwide, falling within the accidental and unintentional injuries has the highest rate among those who are 60 and above (Kibar et.al., 2015: 23).

When there is a decline in cognitive, behavioral and administrative functions of the older person; falling starts. After falling, we see an increase of death and illness rate among the elderly (Naharc1 \& Doruk, 2009: 437). According to the report named "Global Report on Falls

\footnotetext{
${ }^{1}$ Assoc. Prof., Krrikkale University Faculty of Health Sciences, Department of Social Work, hande k1979@yahoo.com

2 Prof. Dr., Hacettepe University Faculty of Economics and Administrative Sciences, Department of Family and Consumer Sciences, erkalsibel@,hotmail.com
} 
Sahin, H., \& Erkal, S. (2017). Evaluation of the elderly' falls efficacy by their status of having a home accident and daily life activities. Journal of Human Sciences, 14(3), 2308-2316. doi:10.14687/ihs.v14i3.4451

Prevention in Older Age" by World Health Organization (WHO); approximately 28-35\% of the people aged 65 and above fall at least once in a year. Half of these falls are repeating falls. The frequency, severity of the falls and the complications about them increase as the age increases and the independence at daily activities decrease and this amount increases to $32-42 \%$ (WHO, 2007: 12).

As age increases, the daily life activities of individual decrease and as individual becomes dependent for others his daily needs are partially covered by friends, family and neighbors; supporting the older person. This causes the exposure of more home accidents and especially falling for older people (Eyigör, 2012: 43; Tel at all., 2011: 59). The factors that cause falling are separated into two groups as individual and environmental factors. Individual risk factors: walking and balance defects, hypertension, dizziness, previous falling history, psycho-active medication utilization, fear, demance and sight problems. Environmental risk factors are wet floor, lack of supportive locations to hold on bath, toilet and bed, door sill, inadequate lighting, existence of non-stable items $\mathrm{n}$ the ground and around (Tanil et.al., 2014: 21). To prevent accidents in the home, at-risk groups should be informed, given safety checklists, and, wherever possible, institute safeguards to prevent accidents at home (Ilce, Ilce, \& Dramali, 2007: 1).

Defection in daily life activities is among the cases that create high risk related with falling (Masud \& Morris, 2001: 3). The literature contains domestic and foreign studies analyzing home accidents of elderly people (Dönmez \& Gökkoca, 2003: 99; Evci at all., 2006: 291; Gillespie, 2004: 653; Erkal \& Şahin, 2016: 195; Martins at all., 2016: 285) and their daily activities (Arpac1, 2015: 46). Studies on this subject have indicated that falling is a widespread thing among the elderly and that the elderly mostly fall within the home and due to factors within the building (Beyazay at all., 2014: 1; Erkal, 2004: 85; Garret \& Menke, 2000: 16; Vieira at all., 2016: 4028). Bu the literature review did not reveal any research conducted on a detailed examination of the falls efficacy of elderly and their relation with home accident and daily life activities. Therefore, this study is planned to examine the falls efficacy of elderly and their relation with home accident and daily life activities.

\section{Methodology Participants}

The universe for this study that aims the examination of the falls efficacy of elderly and their relation with home accident and daily life activities consists of the elderly people aged 65 and above, residing in Cebeci, Ankara, Turkey. Face-to-face interviews were conducted with six hundred people randomly selected within this region who have accepted to participate in the study. After the sampling study, $\mathrm{n}$ is calculated as $384 \mathrm{t}=1.96$ and $\mathrm{d}=0.05$ are calculated for sampling.

\section{Data Gathering}

The questionnaire technique is used for data gathering in the study. Two scales were used in the questionnaire. These are "Modified Falls Efficacy Scale" (MFES), and "Katz Daily Activities Scale". Modified falls Efficacy Scale developed by Tinetti and Richman (1990: 239) and adopted into Turkish by Kaya et.al. (2012: 260).

Modified Falls Efficacy Scale (MFES): Modified Falls Efficacy Scale (MFES), (it determines the feeling of safety resulting from conducting any activity without falling) consists of 14 questions related with some special activities conducted within and outside the home (dressing, bathing, crossing the street etc.). The feeling of safety resulting from conducting any activity without falling is evaluated on a scale of "0" (not safe at all) and "10" (completely safe). Total score is calculated by dividing the arithmetical total of the values for each answer to the number of answered questions. The higher score means higher feeling of safety and higher falls efficacy

Katz Daily Life Activities Scale (KDLA): KDLA index consists of 8 questions containing information on bath, dressing, toilet, action, sitting-standing, walking, cooking, cleaning and shopping. If the individual conducts his daily life activities independently then 3 points is given, 
Şahin, H., \& Erkal, S. (2017). Evaluation of the elderly' falls efficacy by their status of having a home accident and daily life activities. Journal of Human Sciences, 14(3), 2308-2316. doi:10.14687/jhs.v14i3.4451

if he receives help then 2 points is given and if he cannot do them at all then 1 point is given.

\section{Evaluation of Data}

The data analysis is conducted by SPSS 21.0 program. The analysis results revealed that the scale scores had a normal distribution and that group variances were homogeneous. Both parametric (t-test, analysis of variance) and non-parametric (Mann-Whitney U, Kruskal-Wallis $\mathrm{H}$ ) tests were conducted. The significance levels for intergroup difference ( $\mathrm{p}$ values) were very approximate. However, for groups with less than 10 participants, the mean and standard deviation values of only the parametric tests were used in interpretation. In addition, the Tukey's test was employed in the paired comparison of the groups.

\section{Ethical considerations}

Ethical approval was obtained from the Ethics Committee of the Hacettepe University.

\section{Findings}

The findings about the individual characteristics of older persons who have participated in the study are in Table 1. According to this, the majority of the participants in terms of different categories are; male (59.5\%), those between the ages of $65-70(51.5 \%)$, primary school graduates $(40.2 \%)$, those with $892-1500$ TL salaries (34.3\%), those with two children $(34.5 \%)$, those live with their spouse $(45.7 \%)$, those who own their home $(83.8 \%)$ and those who have Artisans as social security $(39.3 \%)$.

Table 1. Distribution of older people according to their individual characteristics

\begin{tabular}{|c|c|c|c|}
\hline Variables & & $\mathrm{n}$ & $\%$ \\
\hline \multirow{2}{*}{ Gender } & Female & 243 & 40.5 \\
\hline & Male & 357 & 59.5 \\
\hline \multirow{5}{*}{ Age } & $65-70$ & 309 & 51.5 \\
\hline & $71-75$ & 102 & 17.0 \\
\hline & $76-80$ & 124 & 20.7 \\
\hline & $81-85$ & 42 & 7.0 \\
\hline & $85+$ & 23 & 3.8 \\
\hline \multirow{4}{*}{ Education } & Primary School & 241 & 40.2 \\
\hline & Secondary School & 135 & 22.5 \\
\hline & High School & 149 & 24.8 \\
\hline & College & 75 & 12.5 \\
\hline \multirow{5}{*}{ Income } & 891 TL and below & 93 & 15.5 \\
\hline & $892-1500 \mathrm{TL}$ & 206 & 34.3 \\
\hline & $1501-2250 \mathrm{TL}$ & 159 & 26.5 \\
\hline & 2251-3000 TL & 95 & 15.8 \\
\hline & 3001 TL and above & 47 & 7.9 \\
\hline \multirow{6}{*}{$\begin{array}{l}\text { Number of } \\
\text { children }\end{array}$} & None & 28 & 4.6 \\
\hline & 1 & 89 & 14.8 \\
\hline & 2 & 207 & 34.5 \\
\hline & 3 & 148 & 24.7 \\
\hline & 4 & 79 & 13.2 \\
\hline & 5 and more & 49 & 8.2 \\
\hline \multirow{5}{*}{ Living........ } & Alone & 112 & 18.7 \\
\hline & With Spouse & 274 & 45.7 \\
\hline & With Relatives & 17 & 2.8 \\
\hline & With Spouse and children & 179 & 29.8 \\
\hline & Other & 18 & 3.0 \\
\hline \multirow{2}{*}{ Housing } & House owner & 503 & 83.8 \\
\hline & Tenant & 97 & 16.2 \\
\hline \multirow{4}{*}{ Social security } & Green card & 76 & 12.7 \\
\hline & Government Retirement Fund & 236 & 39.3 \\
\hline & Social Security for Artisans and Self-Employed & 87 & 14.5 \\
\hline & Social Security Institution & 201 & 33.5 \\
\hline
\end{tabular}


Şahin, H., \& Erkal, S. (2017). Evaluation of the elderly' falls efficacy by their status of having a home accident and daily life activities. Journal of Human Sciences, 14(3), 2308-2316. doi:10.14687/jhs.v14i3.4451

Among the participants, those who had a home accident within the last one year is $24.2 \%$; and among those whose accident type was falling is $54.5 \%$, and slippery floor is $24.1 \%$, lack of attention is $46.2 \%$. Those accidents occurred in kitchen by $27.6 \%$. Those who went to a health institution after the accident is $55.2 \%$. And those who had fully recovered is $80.0 \%$ (Table 2 ).

Table 2. Distribution of the older people according to the variables related with house accident

\begin{tabular}{|c|c|c|c|}
\hline \multirow{2}{*}{$\begin{array}{l}\text { Having an } \\
\text { Accident }\end{array}$} & Yes & 145 & 24.2 \\
\hline & No & 455 & 75.8 \\
\hline \multirow{5}{*}{ Type of Accident } & Falling & 79 & 54.5 \\
\hline & Poisoning & 16 & 11.0 \\
\hline & Burning/Sun-scald & 14 & 9.7 \\
\hline & Cut & 27 & 18.6 \\
\hline & Electric Shock & 9 & 6.2 \\
\hline \multirow{7}{*}{$\begin{array}{l}\text { Reason of } \\
\text { Accident }\end{array}$} & Slippery floor & 35 & 24.2 \\
\hline & Carelesness & 67 & 46.2 \\
\hline & Stuff left around & 10 & 6.9 \\
\hline & Inadequate lighting & 9 & 6.2 \\
\hline & Taking too much medication due to amnesia & 5 & 3.4 \\
\hline & Lack of holding places in Bath-WC & 3 & 2.1 \\
\hline & Other & 16 & 11.0 \\
\hline \multirow{8}{*}{ Area of accident } & Bedroom & 7 & 4.8 \\
\hline & Stairs & 19 & 13.1 \\
\hline & Bathroom & 24 & 16.6 \\
\hline & Kitchen & 40 & 27.6 \\
\hline & Toilet & 6 & 4.1 \\
\hline & Corridor & 13 & 9.0 \\
\hline & Living room & 18 & 12.4 \\
\hline & Garden & 18 & 12.4 \\
\hline \multirow{3}{*}{$\begin{array}{l}\text { Accident } \\
\text { Application }\end{array}$} & Health institution & 80 & 55.2 \\
\hline & Nowhere & 58 & 40.0 \\
\hline & Other (bone setter, neighbor, acquaintance) & 7 & 4.8 \\
\hline \multirow{3}{*}{ Result of Accident } & Full recovery & 116 & 80.0 \\
\hline & Ongoing treatment & 18 & 12.4 \\
\hline & Disability & 11 & 7.6 \\
\hline
\end{tabular}

The variance analysis results for the comparison of the falls efficacy scores of the participants with respect to dependence-independence during bathing, dressing, sitting/standing, toilet, walking, cooking, cleaning and shopping activities presented in Table 3 revealed significant differences between all the groups $(\mathrm{p}<0.01)$. The falls efficacy scores of the participants increased with independence in bathing, dressing, sitting/standing, toilet, walking, cooking, cleaning and shopping activities (i.e. efficacy decreased as dependence increased) (Table 3). 
Şahin, H., \& Erkal, S. (2017). Evaluation of the elderly' falls efficacy by their status of having a home accident and daily life activities. Journal of Human Sciences, 14(3), 2308-2316. doi:10.14687/jhs.v14i3.4451

Table 3. Comparison of falls efficacy scores by dependence in daily life activities

\begin{tabular}{|c|c|c|c|c|c|}
\hline Variable & Group & $\mathbf{n}$ & $\bar{X}$ & $\mathbf{F}$ & $\mathrm{p}$ \\
\hline \multirow{3}{*}{ Bathing } & Dependent & 29 & $30,17^{\mathrm{c}}$ & \multirow{3}{*}{141,23} & \multirow{3}{*}{$0,000^{*}$} \\
\hline & Semi-Dependent & 73 & $64,17^{\mathrm{b}}$ & & \\
\hline & Independent & 498 & $86,02^{\mathrm{a}}$ & & \\
\hline \multirow{3}{*}{ Dressing } & Dependent & 10 & $19,70^{c}$ & \multirow{3}{*}{90,217} & \multirow{3}{*}{$0,000^{*}$} \\
\hline & Semi-Dependent & 44 & $52,61^{\mathrm{b}}$ & & \\
\hline & Independent & 546 & $84,04^{a}$ & & \\
\hline \multirow{3}{*}{ Sitting/Standing } & Dependent & 9 & $34,00^{c}$ & \multirow{3}{*}{62,534} & \multirow{3}{*}{$0,000^{*}$} \\
\hline & Semi-Dependent & 38 & $50,65^{\mathrm{b}}$ & & \\
\hline & Independent & 553 & $83,48^{a}$ & & \\
\hline \multirow{3}{*}{ Toilet } & Dependent & 5 & $31,40^{c}$ & \multirow{3}{*}{99,774} & \multirow{3}{*}{$0,000^{*}$} \\
\hline & Semi-Dependent & 35 & $37,08^{\mathrm{b}}$ & & \\
\hline & Independent & 560 & $83,82^{a}$ & & \\
\hline \multirow{3}{*}{ Walking } & Dependent & 7 & $22,85^{c}$ & \multirow{3}{*}{88,189} & \multirow{3}{*}{$0,000^{*}$} \\
\hline & Semi-Dependent & 31 & $41,09^{\mathrm{b}}$ & & \\
\hline & Independent & 562 & $83,56^{a}$ & & \\
\hline \multirow{3}{*}{ Cooking } & Dependent & 46 & 34,63 & \multirow{3}{*}{248,232} & \multirow{3}{*}{$0,000^{*}$} \\
\hline & Semi-Dependent & 97 & 64,48 & & \\
\hline & Independent & 457 & 88,73 & & \\
\hline \multirow{3}{*}{ Cleaning } & Dependent & 50 & $35,86^{c}$ & \multirow{3}{*}{220,535} & \multirow{3}{*}{$0,000^{*}$} \\
\hline & Semi-Dependent & 163 & $72,74^{b}$ & & \\
\hline & Independent & 387 & $89,78^{\mathrm{a}}$ & & \\
\hline \multirow{3}{*}{ Shopping } & Dependent & 46 & $31,36^{c}$ & \multirow{3}{*}{295,711} & \multirow{3}{*}{$0,000^{*}$} \\
\hline & Semi-Dependent & 150 & $69,76^{\mathrm{b}}$ & & \\
\hline & Independent & 404 & $90,32^{\mathrm{a}}$ & & \\
\hline
\end{tabular}

The analysis of variance and t-test results for the comparison of the participants' falls efficacy scores with respect to various individual characteristics are presented in Table 4. The mean overall falls efficacy scores displayed a significant difference for all groups with respect to the given variables $(\mathrm{p}<0.01)$. The mean overall falls efficacy scores indicated that the level of efficacy decreased systematically for each group over the age of 75 . In addition, college and primary school graduates had the highest $(\overline{\mathrm{X}}=95.25)$ and the lowest $(\overline{\mathrm{X}}=73.51)$ falls efficacy scores, respectively. Similarly, the participants with the lowest (891 TL and below) and the highest (3001 TL and over) monthly incomes had the lowest $(\overline{\mathrm{X}}=60.21)$ and highest $(\overline{\mathrm{X}}=93.19)$ falls efficacy scores, respectively. Furthermore, the participants who lived with relatives or other people had lower falls efficacy scores than those who lived alone, with their spouses or with their spouses and children. The participants with green cards also had lower efficacy scores than those with other social security alternatives. The t-test results showed that the falls efficacy scores of the participants displayed a significant difference with respect to whether or not the participant had had a home accident within the past year $(\mathrm{p}<0.01)$. Those who had not experienced a home accident within the past year $(\overline{\mathrm{X}}=84.33)$ had a higher level of falls efficacy than those who had ( $\overline{\mathrm{X}}=69.15)$. 
Şahin, H., \& Erkal, S. (2017). Evaluation of the elderly' falls efficacy by their status of having a home accident and daily life activities. Journal of Human Sciences, 14(3), 2308-2316. doi:10.14687/jhs.v14i3.4451

Table 4. Comparison of falls efficacy scores by various individual characteristics

\begin{tabular}{|c|c|c|c|c|c|}
\hline Variable & Group & $\mathrm{n}$ & $\overline{\mathrm{X}}$ & $F / t$ & $\mathrm{p}$ \\
\hline \multirow{5}{*}{ Age } & $65-70$ & 309 & $90,38^{a}$ & \multirow{5}{*}{63,019} & \multirow{5}{*}{$0,000^{*}$} \\
\hline & $71-75$ & 102 & $83,01^{a}$ & & \\
\hline & $76-80$ & 124 & $69,49^{\mathrm{b}}$ & & \\
\hline & $81-85$ & 42 & $55,73^{\mathrm{c}}$ & & \\
\hline & $85+$ & 23 & $45,34^{\mathrm{d}}$ & & \\
\hline \multirow{4}{*}{ Education } & Primary School & 241 & $73,51^{\mathrm{c}}$ & \multirow{4}{*}{19,654} & \multirow{4}{*}{$0,000^{*}$} \\
\hline & Secondary School & 135 & $81,34 \mathrm{~b}$ & & \\
\hline & High School & 149 & $84,26^{\mathrm{b}}$ & & \\
\hline & College & 75 & $95,25^{\mathrm{a}}$ & & \\
\hline \multirow{5}{*}{ Monthly income } & 891 TL and below & 93 & $60,21^{\mathrm{d}}$ & \multirow{5}{*}{26,531} & \multirow{5}{*}{$0,000^{*}$} \\
\hline & $892-1500 \mathrm{TL}$ & 206 & $81,99^{\mathrm{b}}$ & & \\
\hline & 1501-2250 TL & 159 & $84,80^{\mathrm{b}}$ & & \\
\hline & 2251-3000 TL & 95 & $84,66^{\mathrm{b}}$ & & \\
\hline & 3001 TL and above & 47 & $93,19^{a}$ & & \\
\hline \multirow{5}{*}{ Living......... } & Alone & 112 & $78,04^{a}$ & \multirow{5}{*}{5,748} & \multirow{5}{*}{$0,000^{*}$} \\
\hline & With Spouse & 274 & $82,45^{a}$ & & \\
\hline & With Relatives & 17 & $61,94^{b}$ & & \\
\hline & With Spouse and children & 179 & $82,83^{a}$ & & \\
\hline & Other & 18 & $65,66^{\mathrm{b}}$ & & \\
\hline \multirow{4}{*}{ Social security } & Green card & 76 & $58,59^{\mathrm{b}}$ & \multirow{4}{*}{33,402} & \multirow{4}{*}{$0,000^{*}$} \\
\hline & Government Retirement Fund & 236 & $82,59^{a}$ & & \\
\hline & $\begin{array}{l}\text { Social Security for Artisans } \\
\text { and Self-Employed }\end{array}$ & 87 & $78,39^{a}$ & & \\
\hline & Social Security Institution & 201 & $87,72^{\mathrm{a}}$ & & \\
\hline
\end{tabular}

${ }^{*} p<0,01 ;{ }^{a, b, c, d}$ : the differences between groups indicated with different letters are significant.

\section{Discussion}

Among those who have participated in the study, the rate of having a home accident is 24.2\%. In the study of Dönmez and Gökçekoca (2003: 99) this rate was $19.4 \% ; 29.0 \%$ in the study of Tortumluoğlu et all (2005: 22); 20.6\% in the study of Doğan et all (2010: 651); and 40\% in the study of Ortabağ et al (2011: 189). The reason of the difference between the frequencies of home accidents of older people may stem from the arrangements of the places where they live in accordance with accidents, socio-economic level and the individual differences.

Falling is the most frequent reason of injury among the older people (Horan, 1999: 895). In this study, the most frequent accident type among the older people who had a home accident is falling (54.5\%). This finding is similar with the findings of Sattin et all (1990: 1028), Scott and Gallogher (1999: 343), Lee et.al. (1999: 96), Topaç (2002:37), Dönmez and Gökcekoca (2003: 99), Evci et al (2006: 291), Gutman (2007: 1), Alptekin et al (2008: 535). These studies support the result of our study. These findings indicate that falling is a widespread problem for elderly people.

Those who say that carelessness was the main reason of accident $(46.2 \%)$ are the first group; and they are followed by those who say that the reason is slippery floor $(24.1 \%)$. This finding gives rise to the thought that the older people have to be more cautious against the home accidents and that arrangements should be done within the home in order to prevent the accident. The study conducted by Lach et.al. (1991: 197) on older people indicates that those who fell because of slippery surfaces are on the top of list. Topaç's (2002:42) study states the following as the top five reasons of accidents among the older people: inadequate lighting, carpets, forgotten items or those items placed on the walking trail, items with sharp and hard edges and wet floor. 
Şahin, H., \& Erkal, S. (2017). Evaluation of the elderly' falls efficacy by their status of having a home accident and daily life activities. Journal of Human Sciences, 14(3), 2308-2316. doi:10.14687/jhs.v14i3.4451

Study has indicates that the accidents mostly happened in the kitchen $(27.6 \%)$. The reason of this can be explained as the older people spending more time in the kitchen during their daily life activities and with the existence of too many sharp tools within this area which may cause accidents. According to the study of Clemson et al. (1996: 97) in which they analyzed home accidents and fallings in people aged 65 years and older, elderly people experienced falling mostly in bathroom and restroom. The study of Lee et.al. (1999: 96) has indicated the toilet as the area where majority of accidents occur.

The rate of those who apply to a health institution after the accidents is $55.2 \%$; those who do not apply anywhere is $40.0 \%$ and those who apply to other (bone setter, neighbor) is $4.8 \%$; whereas the rate for those who have fully recovered after the accidents is $80.0 \%$. The study conducted by Tortumluoğlu et.al. (2005: 22) has stated that more than half of the older people who had an accident have applied to a health institution (56.6\%).

The study results showed that the falls efficacy scores of the participants displayed a significant difference with respect to home accident status $(p<0.01)$ and the falls efficacy levels of the older adults who had not experienced a home accident within the past year $(\bar{X}=84,33)$ were higher than those who had $(\overline{\mathrm{X}}=69,15)$. The high score of Modified Falls Efficacy Scale (MFES) among those older people who did not have an accident can be related with their environment which has more secure conditions in terms of accident risk and the higher security feeling for the accomplishment of daily activities within the home.

There were significant differences between all the groups with respect to dependenceindependence during bathing, dressing, sitting/standing, toilet, walking, cooking, cleaning and shopping activities $(\mathrm{p}<0.01)$. The results revealed that the falls efficacy scores of the participants increased with independence in bathing, dressing, sitting/standing, toilet, walking, cooking, cleaning and shopping activities (i.e. efficacy decreased with increased dependence). The high score of Modified Falls Efficacy Scale (MFES) of those older people who could execute several activities independently could be stemmed from the fact that they are physically more comfortable and active and that they have a higher level of self-confidence as they can act independently. Scheffer et.al. (2008: 19) have emphasized in their study that the fear of Falling affects the feeling of confidence during the daily life activities, thereby increasing the risk of falling. Kaya et. al (2012) have stated that those older people who have stated their fear of falling had lower Modified Falls Efficacy Scale (MFES) scores; therefore having more concerns in terms of accomplishing the daily activities.

The mean overall falls efficacy scores displayed a significant difference for all groups with respect to the given variables $(\mathrm{p}<0.01)$. The mean overall falls efficacy scores indicated that the level of efficacy decreased systematically for each group over the age of 75 . Furthermore, college and primary school graduates had the highest $(\overline{\mathrm{X}}=95.25)$ and the lowest $(\overline{\mathrm{X}}=73.51)$ falls efficacy scores, respectively. Similarly, the participants with the lowest (891 TL and below) and highest (3001 TL and over) monthly incomes had the lowest $(\bar{X}=60.21)$ and highest $(\bar{X}=93.19)$ falls efficacy scores, respectively. In addition, the participants who lived with relatives or other people had lower falls efficacy scores than those who lived alone, with their spouses or with their spouses and children. The participants with green cards also had lower efficacy scores than those with other social security alternatives. As a result of our study, we have seen that those who live alone, who have lower monthly income, who are younger, who have green card have a lower average on Modified Falls Efficacy Scale (MFES); which means that they are not aware of home accident risks and therefore they need to act more carefully. Also, it is interesting that those with lower ages have lower falls efficacy rate; and this should be examined in different studies. Kaya et.al. (2012: 260) have stated in their study that the age difference is statistically distinguishing in the group with no Falling story; and those who have lower falls efficacy scores with no falling story are older than those with higher scores. 
Şahin, H., \& Erkal, S. (2017). Evaluation of the elderly' falls efficacy by their status of having a home accident and daily life activities. Journal of Human Sciences, 14(3), 2308-2316. doi:10.14687/jhs.v14i3.4451

The study indicates that as the level of education increases, Modified Falls Efficacy Scale (MFES) score increases in parallel. This result indicates how effective education is.

\section{Result and Recommendations}

Studies on this subject have indicated that falling is a widespread thing among the elderly and that the elderly mostly fall within the home and due to factors within the building. The literature review did not reveal any research conducted on a detailed examination of the falls efficacy of elderly and their relation with home accident and daily life activities. This study, unlike the other studies, revealed the falls efficacy of elderly and their relationship with home accidents and daily life activities.

-The results showed that the falls efficacy scores of the older adults who had experienced a home accident within the past year were lower than those who had not.

-The falls efficacy scores of the participants decreased with increased dependence in bathing, sitting/standing, toilet, walking, cooking, cleaning and shopping activities.

-The older individuals who have stated that they were independent while conducting the activities related with home had more positive opinions than those older individuals who have said they were dependent.

-The participants who were older, had lower educational attainment, low monthly income and green cards, and lived with their relatives had lower falls efficacy scores $(p<0.05)$.

According to the findings of the results;

- In service training programs should be prepared in order to prevent the risks and falling that may cause falling within the home for the individuals who provide care services for older people, and the older individuals themselves.

- Making the necessary arrangements to prevent in-home accidents within the home in order to help the older people live as physically active individuals.

- To take the safety measures in the home to prevent falling,

- To make wider studies in Turkey about this subject and to make the necessary arrangements accordingly.

\section{Limitations}

Several limitations must be acknowledged. First and foremost, the sample size of the current study is small, which limited the analyses we were able to conduct. Second, measurement of Modified Falls Efficacy Scale (MFES) and life daily life activities only by self-report.

\section{References}

Alptekin F, Uskun E, Kisioğlu AN, Ozturk M (2008). Unintentional non-fatal home-related injuries in Central Anatolia, Turkey: Frequencies, characteristics, and outcomes. Injury 39 (5): 535-546.

Arpacı F (2015). Yaşlı bireylerin yaşam kalitesi açısından günlük yaşam aktivitelerini yapabilme durumunun incelenmesi. Elderly Issues Research Journal 1: 46-53.

Beyazay S, Durna Z, Akın, S (2014). Yaşlı bireylerde düşme riski ve etkileyen faktörlerin değerlendirilmesi. Türkiye Klinikleri Journal of Nursing Science 6 (1): 1-12.

Clemson L, Cumming RG, Roland M (1996). Case-control study of hazards in the home and risk of falls and hip fracture. Age Ageing 25 (2): 97-101.

Çınarlı T, Koç Z (2015). 65 yaş ve üzeri yaşlllarda düşme risk ve korkusunun günlük yaşam aktiviteleri ve yaşam kalitesi üzerine etkisi. Gumushane University Journal of Health Sciences 4 (4): 660-679.

Doğan H, Canbaz S, Tander B, Pekşen Y, Cantürk F, Özal Oruç N (2010). The prevalence of home injuries among elderly people in Samsun, Turkey, and the influencing factors. Turkish Journal of Medical Sciences 40 (4): 651-658.

Dönmez L, Gokcekoca Z (2003). Accident profile of older people in Antalya city center, Turkey. Archives of Gerontology and Geriatrics 37 (2): 99-108.

Erkal S (2004). Kırıkkale Ovacık Mahallesinde Yaşayan 65 Yaş ve Üzerindeki Kişilerin Ev Kazalarına Karşı Önlem Alma Durumlarının İncelenmesi Sağlık ve Toplum Dergisi 14 (4): 85-90. 
Şahin, H., \& Erkal, S. (2017). Evaluation of the elderly' falls efficacy by their status of having a home accident and daily life activities. Journal of Human Sciences, 14(3), 2308-2316. doi:10.14687/jhs.v14i3.4451

Erkal, S., Şahin, H. (2016). Evaluation of home accidents and fall behaviors of elderly. Turkish Journal of Geriatrics 19 (3): 195-201.

Evci ED, Ergin F, Beşer E (2006). Home accidents in the elderly in Turkey. The Tohoku Journal of Experimental Medicine 209 (4): 291-301.

Eyigör S (2012). Düşmelere yaklaşım. Ege Tip Dergisi 51: 43-51.

Garret MD, Menke KA (2000). Falls among the elderly at the st michael geriatric hospital. Quarterly Journal of The International Institute Ageing 10 (2): 16-23.

Gillespie L (2004). Preventing falls in elderly people. British Medical Journal 328 (7441): 653-654.

Gutman GM (2007). Home accidents amongst elderly people: A locality study in Scotland. Gerobilim 1: 112.

Horan MA, Clague JE (1999). Injury in the aging recovery and rehabilitation. Bri.Med.Bull. 55 (4): 895909.

İlçe AÖ, İlçe AC, Dramalı A (2007). Yaşlılarda ev kazalarının önlenmesi ve ev kazalarının önlenmesine yönelik iç mekan düzenlemeleri. Sosyolojik Araştırmalar E. Dergisi 7: 1-17

Kaya T, Karatepe AG, Avc1 A, Günaydın R (2012). Yaşlılarda düşme korkusu ve düşmeye karşı yetkinlik. Turkish Journal of Geriatrics 15 (3): 260-265.

Kibar E, Aslan D, Karakoç Y, Kutsal YG (2015). Ankara'da bir kurumda yaşayan yaşlılar arasında düşme sağlı̆ı, risk faktörleri ve korunmaya ilişkin yaklaşımlar. TAF Preventive Medicine Bulletin 14 (1): 23-32.

Lach HW, Reed AT, Arfken CL, Miller JP, Paige GD, Birge SJ, Peck WA (1991). Falls in the elderly: reliability of a classification system. Journal of American Geriatrics Society 39 (2): 197-202.

Lee VM, Wong TW, Lau CC (1999). Home accidents in elderly patients presenting to an emergency department. Accident and Emergy Nursing 7 (2): 96-102.

Martins, L., Barkokébas, B., Baptista, J., Arezes, P. (2016). Domestic safety and accidents risk perception by active elderly. Advances in Safety Management and Human Factors 491: 285-295.

Masud T, Morris RO (2001). Epidemiology of falls. Age and Aging 30 (4): 3-7.

Naharcı MI, Doruk H (2009). Yaşlı popülasyonda düşmeye yaklaşım. TAF Preventive Medicine Bulletin 8 (5): 437-444.

Ortabağ T, Özdemir Ö, Kılıç S (2011). Özel bakım evlerinde yaşayan yaşlı bireylerin ev kazalarına yönelik riskli davranışlarının belirlenmesi. Gülhane Tip Dergisi 53: 189-194.

Sattin RW, Lambert Huber DA, DeVito CA, Rodriguez JG, Ros A, Bacchelli S, Stevens JA, Waxweiler RJ (1990). The incidence of fall injury events among elderly in a defined population. American Journal of Epidemiology 131 (6): 1028-1037.

Scheffer AC, Schuurmans MJ, Dijk NV, Van der Hooft T, De Rooij S (2008). Fear of falling: measurement strategy, prevalence, risk factors and consequences among older persons. Age Aging 37 (1): 19-24

Scott VJ, Gallogher EM (1999). Mortality and morbidity related to injuries from fall in British Columbia. Canadian Journal of Public Health 90 (5): 343-7.

Tanıl V, Çetinkaya Y, Sayer V, Avşar D, İskit Y (2014). Düşme riskinin değerlendirilmesi. Sağlık Akademisyenleri Dergisi 1 (1): 21-26.

Tel H, Güler N, Tel H (2011). Yaşlıların evde günlük yaşam aktivitelerini sürdürme durumu ve yaşam kaliteleri. Hemşirelikte Araştırma Geliştirme Dergisi 2: 59-67.

Tinetti ME, Richman D, Powell L (1990). Falls efficacy as a measure of fear of falling. Journal of Gerontology 45 (6): 239-243.

Topaç Ş (2002). Gata Eğitim Hastanesinde rutin incelemeye tabi tutulan yaşlı bireylerde ev kaza sıklığı, kaza özellikleri ile nedenleri ve bunun yaşadıkları konut özellikleri ile ilişkisi. Yüksek Lisans Tezi, Gülhane Askeri Tip Akademisi, Ankara.

Tortumluoğlu G, Akyll R, Özer N (2005). Yaşlılarda ev kazaları prevelansı ve etkileyen faktörler. Atatürk Üniversitesi Hemşirelik Yüksekokulu Dergisi 8 (2): 22-31.

Türkiye İstatistik Kurumu (TUIK) (2014). Elderly statistics 2014. Ankara: Türkiye İstatistik Kurumu Matbaasi.

Vieira, B., Plácido, C., Rocha, S., , Cláudia, A., Plácido, A.C., Mayara, G. (2016). Risk factors associated with falls in elderly. Journal of Nursing UFPE / Revista de Enfermagem UFPE 10(11): 4028-4035.

WHO (2007). WHO Global report on falls prevention in older age 2007. Genava: WHO Library Cataloguing in Publication. 